\title{
A Morfologia Distribuída no Brasil: duas décadas de existência
}

\author{
Distributed Morphology in Brazil: two decades of \\ existence
}

Miriam Lemle Universidade Federal do Rio de Janeiro Ana Paula Scher Universidade de São Paulo Maria Cristina Figueiredo Silva* Universidade Federal do Paraná Alessandro Boechat de Medeiros Universidade Federal do Rio de Janeiro

Resumo

Este artigo é um conjunto de quatro testemunhos de pesquisadores brasleiros que se apaixonaram pela Morfologia Distribuída desde a publicação do artigo inaugural de autoria de Morris Halle e Alec Marantz, "Distributed morphology and the pieces of inflection", em 1993. Essa teoria propõe uma nova arquitetura de gramática que tem muito em comum com a sintaxe e pouco a ver com a morfologia tradicional - por exemplo, o antigo léxico é decomposto em três diferentes listas. Cada um dos contribuidores foi convidado a responder as seguintes questões: (i) Qual foi a característica da Morfologia Distribuída que levou você a gostar mais dessa versão da gramática gerativa?; (ii) Qual foi o primeiro tema que você mesma/mesmo explorou com base nessa teoria?; (iii) Por que razão esse modelo parece a você mais vantajoso do que o modelo gerativo tradicional de morfologia?; (iv) Que outros temas você incentivou e vem incentivando alunos seus a explorar, 
e que interfaces do modelo ganham foco em cada caso?; (v) Em que novas questôes você tem vontade de trabalhar a curto prazo?

\section{Palavras-Chave}

Morfologia Distribuída, Gramática Gerativa, Português Brasileiro.

\section{Abstract}

This paper is a set of four testimonies from Brazilian researchers who fell in love with Distributed Morphology after the publication of the inaugural article by Morris Halle and Alec Marantz, "Distributed morphology and the pieces of inflection", in 1993. This theory proposes a new architecture of grammar that has a lot in common with syntax and little to do with traditional morphology - for example, the ancient lexicon is broken down into three different lists. Each of the contributors was invited to answer the following questions: (i) What is the feature of Distributed Morphology that leads you to prefer this version of generative grammar to ground your work?, (ii) What was the first subject you explored based on this theory?, (iii) Why does this model seem to you more interesting than the traditional generative one?, (iv) Which subjects did you encourage your students to explore in the past and which ones do you currently encourage? What are the interfaces of the grammar that are highlighted in each case?, (v) Which questions do you plan to explore in the near future?

\section{Keywords}

Distributed morphology, Generative Grammar, Brazilian Portuguese. 


\section{Introdução}

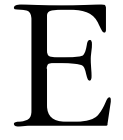

ste artigo se estrutura como um conjunto de quatro depoimentos de professores brasileiros que se apaixonaram pela Morfologia Distribuída (doravante MD) desde (algum tempo depois d)a publicação do texto inaugural dessa vertente teórica, intitulado "Distributed morphology and the pieces of inflection", de Morris Halle e Alec Marantz em 1993, no famoso The view from building 20. É verdade que o livro é famoso porque nele está uma formulação completa do programa minimalista feita por Chomsky de próprio punho, digamos assim, mas outros textos que povoam o livro revelam a efervescência teórica do período.

A MD é uma teoria morfológica que tem pouco em comum com a morfologia tradicional, a começar pelo tratamento que dá à entidade 'palavra' - um epifenômeno nesse quadro teórico. Na verdade, a teoria tem muito em comum com a sintaxe, por admitir como pressuposto que só existe um mecanismo que gera as construçôes da língua, sejam elas de que "tamanho" for: palavras, sintagmas, frases...

O modelo da MD foi proposto em Halle e Marantz (1993) e trabalhos subsequentes. Essa teoria propõe uma arquitetura para a gramática que dispensa o componente lexical, da forma como a gramática gerativa dos anos 70 e 80 concebia esse componente. Assim, a tarefa atribuída ao componente lexical em propostas teóricas anteriores à MD se espalhou, nesse modelo, por, pelo menos, três listas de elementos de natureza diferentes e descritas, de forma bastante breve, com: lista 1, de traços morfossintáticos abstratos com os quais a sintaxe opera e forma derivaçôes que serão enviadas ao componente morfológico; lista 2 , de itens vocabulares que, na realidade, são regras que regulam a inserção de material fonológico nos terminais morfossintáticos, abstratos resultantes da derivação sintática à qual se aplicam operações morfológicas variadas; lista 3, de significados especiais. 
Não somos tantos - ainda! - os apaixonados por essa maneira de ver a morfologia (e em última instância a gramática) das línguas naturais - e talvez uma expectativa deste nosso artigo seja despertar no leitor a mesma paixão que sentimos. Por isso, entendemos que a melhor maneira de organizar o texto é como um conjunto de depoimentos pessoais que contemplem em alguma medida as questôes que se seguem:

(i) Qual foi a característica da Morfologia Distribuída que levou você a gostar mais dessa versão da gramática gerativa?

(ii) Qual foi o primeiro tema que você mesma / mesmo explorou com base nessa teoria?

(iii) Por que razão esse modelo parece a você mais vantajoso do que o modelo gerativo tradicional de morfologia?

(iv) Que outros temas você incentivou e vem incentivando alunos seus a explorar, e que interfaces do modelo ganham foco em cada caso?

(v) Em que novas questôes você tem vontade de entrar, a curto prazo?

Assim, cada uma das seçôes que se seguem apresenta um dos quatro autores falando de sua aproximação e seu trabalho com a MD. Em 2.1, temos os depoimentos de Miriam Lemle e de Alessandro Boechat de Medeiros, ambos da UFRJ; em 2.2, a contribuição de Ana Paula Scher na USP; finalmente, em 2.3, está a contribuição de Maria Cristina Figueiredo Silva, primeiro na UFSC e agora na UFPR. A última seção conclui o artigo, trazendo uma breve reflexão dos autores sobre o impacto dessa teoria no mundo da ciência da linguagem e sobre o fazer científico no nosso campo do saber.

\section{Morfologia Distribuída na Universidade Federal do Rio de Janeiro}

\subsection{Depoimento de Miriam Lemle, professora emérita do Departamento de Linguística e Filologia da UFRJ: Por que gosto da Morfologia Distribuída}

A minha iniciação à gramática gerativa aconteceu no ano de 1962, quando li Syntactic Structures num exemplarzinho usado que ganhei de um doutorando americano de Antropologia, estagiário no Museu Nacional, que me disse que precisava diminuir o peso de sua bagagem e everybody is reading that. Lá pela página 14, compreendi, assustada, que aquele fino livrinho azul era algo 
totalmente novo, diverso de tudo aquilo que até então eu sabia sobre saberes, língua, línguas, sintaxe. $\mathrm{O}$ desejo de aprender a posicionar-me daquela maneira pensante se agarrou em mim então. "Por que a gramática gerativa vive mudando?!" me foi indagado várias vezes nesta vida. Viver mudando não é o estado normal do processo de querer saber?

O Mestrado na Pennsylvania, onde 'a gerativa' já fora incorporada, ajudou muito. Mas era preciso ler por conta própria, e em 1965, quando voltei, Mestra, de Philadelphia, trazia na mala Aspects of the Theory of Syntax, que li por conta própria e resenhei para a revista Tempo Brasileiro 14/15. A essas alturas as pósgraduações já estavam se formando e a gramática gerativa recebeu espaço. De súbito, um tsunami chamado 'semântica gerativa' alegava a superação teórica do modelo Aspects de gramática. Essa foi uma proposta estapafúrdia e ruidosa, que não merecia ter ganho os espaços que ganhou nas boas revistas de linguística no fim dos anos sessenta. $\mathrm{O}$ tal modelo 'revolucionário' pretendia retirar a sintaxe do meio do caminho entre o pensamento e a fala, e para isso hipertrofiava irrestritamente, tornando-o onipotente, o emprego do termo 'transformação', com o objetivo de ir homogeneamente do céu ao chão; derivava-se com essa ferramenta, por exemplo, o verbo kill passo a passo a partir do seu significado etéreo cause someone go to dead; o verbo remind, em John reminds me of a gorilla, passo a passo a partir do significado cause someone to think about something.

A resposta de Chomsky aos jovens revolucionários foi Remarks on Nominalizations, cuja leitura me trouxe, por um lado, uma pitada de desânimo, mas também um grande alívio. $\mathrm{O}$ desânimo foi pela pouca chance visível para participar criativamente, à distância, no empreendimento gerativista. $\mathrm{O}$ alívio foi devido ao resgate que Chomsky no Remarks fazia do chamado modelo T, com o consequente descarte do desestruturado 'modelo homogêneo' da semântica gerativa. Ele ali trouxe de volta a motivação da distinção entre relações sintáticas decorrentes das regras da base e relaçóes sintáticas provenientes de transformaçóes. As regras de base tinham a forma de regras de phrase structure somente, e ao fornecerem variados contextos sintáticos, autorizavam, em cada contexto, leituras semânticas diferentes; as regras de transformação operam deslocamentos que não resultam em diferenças de significado. Regras de phrase structure para NPs são desenhadas, e abarcam o artigo e possessivos à esquerda e complementos à direita do nome núcleo. Os nomes relacionados a verbos de maneira semanticamente idiossincrásica receberiam, então, o seu significado, segundo essa divisão, no interior do contexto sintático típico de nomes, e não de verbos. 
Os nomes dados como exemplo do distanciamento semântico entre verbos e nomes cognatos são laughter, marriage, construction, actions, activities, revolution, belief, doubt, conversion, permutation, trial, residence, qualifications, specifications, and so on (p. 19). O rótulo de 'lexicalista' que Chomsky aplica à sua teoria, nesse artigo, serve principalmente para distingui-la da 'transformacionalista', a teoria irrestrita que ele precisava invalidar. E finalizou o artigo considerando uma solução lexicalista para a alternância entre grow transitivo e grow intransitivo: com a proposta de um traço [causativizador] para o verbo grow no contexto transitivo, como em John grows tomatoes, considerou ter posto a salvo o modelo lexicalista, pois o traço fornecia o contexto sintático para a agentivização do verbo. Com essa última proposta com que encerrava o artigo, Chomsky não percebeu a brecha que abriu: o léxico teria dentro dele sintaxe também, uma sintaxe dotada de unidades fonologicamente nulas, como o traço causativizador. Mas ao menos o modelo T, resgatado do tsunami semântico-gerativista, voltou a ser uma terra firme sobre a qual tínhamos estruturas sintáticas que recebiam leitura semântica, umas regras restritas de 'transformação', basicamente deslocamentos sintáticos, que não afetavam a leitura dos papeis temáticos, e um léxico, repositório de peças monomorfêmicas e também peças morfologicamente complexas com leitura composicional e peças morfologicamente complexas ambíguas, com uma leitura composicional e outra idiossincrásica, conforme ilustravam aqueles quatorze exemplos da página 19.

Vida que segue, com a incômoda ausência da explicação do como e do porquê existem constituintes sintáticos recebendo leitura composicional e constituintes sintáticos recebendo leitura idiomática, do como e do porquê existem verbos ambíguos, e uma persistente obscuridade para o mapa do órgão gramatical no seu todo, com orquestração de seus subsistemas e interfaces. Carências insuportáveis.

Passei o ano letivo de 1973/74 como Special Student no MIT, e lá frequentei o curso de Morris Halle (Fonologia) e o de Chomsky (Sintaxe). Halle volta e meia fazia umas análises em que propunha fonemas com underspecified features que se tornavam plenamente especificados segundo o contexto gramatical. Havia também uns underspecified morphemes que ganhavam mais traços ao serem inseridos na sintaxe e... Apagando do quadro essas análises, Halle resmungava algo como "but Noam does not want to do it this way". Boiava, eu. Noam, por sua vez, em sua aula, volta e meia explicava alguma alternância morfossintática à sua maneira (lexicalista), e, com um gestinho curto da mão aberta para fora, como 
se entregasse ao ar uma pergunta perigosa, encerrava: "If that's the right way to do it at all..." ai-meu-deus, pensava eu...

Ali há dissonância, voltei para casa, aguardando... Aguardando, estudei na solidão dos trópicos fenômenos isolados, inversóes estilísticas em poemas latinos, língua de sinais... esperando!

Demorou: Distributed Morphology and the pieces of inflection, Halle e Marantz, 1993, no volume The View from Building 20. O segredo desvendado: uma teoria completa. Por ora, dá para estudar, mas estou crua para ensinar. Pouco depois, outro tijolo parecido dessa mesma dobradinha, em 1994: Some key features of Distributed Morphology, em Working Papers in Linguistics 21 do MIT. Aprendo a procurar handouts de Marantz, decodificá-los, até que um dia consigo um com título insolente: No escape from syntax; don't try morphological analysis in the privacy of your own lexicon. Maravilha: esse artigo guerreiro de Marantz 1997, redigido de maneira legível, ajuda a reler o texto inaugural oficial da MD, o do volume de 1993.

A partir de 1998 experimento apresentar o que entendi da MD em sala de aula. Com essa maneira de ver a gramática, adquire alguma forma, até que, enfim, a ideia do 'órgão da mente'. Uma orquestra biológica com instrumentos diversos dialogando: um gera a partitura de um cantar sem voz (a sintaxe), que entrega, fase a fase, os hieróglifos de sua partitura a dois outros instrumentos. Um deles é a morfologia. Esta os lê como instruções para reagrupá-los, categorizar segmentos e transcrevê-los já em alfabeto fonológico, entregando-os para outra oficina, a fonologia, que manda instruçôes sobre a pronúncia para o sistema de produção de fala. Do outro lado, os hieróglifos da partitura sintática são entregues a um outro aparelho leitor, a semântica, que traduz para sinais legíveis aqueles quinhōes de segmentos categorizados. Tudo isso pode ser mostrado, para fins didáticos, por meio de um excelente texto com uma figura que se presta para ser impressa como cartaz. Venho usando-o proveitosamente em salas de aula desde o ano 2000, e recomendo a todos os professores que façam o mesmo, com o esquema da MD oferecido na página 2 do artigo de Heidi Harley e Rolf Noyer de 1999, State-of-the-article: Distributed morphology.

A essas alturas, a bibliografia de MD cresceu, vai se adensando e fui descobrindo outros nomes: Heidi Harley, James Harris, Rolf Noyer, David Embick, Hagit Borer. Em 2003, trouxemos para o Instituto da Abralin, que estava, então, na UFRJ, a pesquisadora-linguista Heidi Harley, que deu um excelente minicurso introdutório para um auditório menos lotado do que o dos 
meus sonhos, em que nos sentávamos juntos, estudantes atentos, a Ana Scher, a Aniela Improta, a Aleria Lage, o Alessandro Boechat e eu, orientados e orientandos, orientadores de então e do futuro. Em 2007, eu já sabia que a Maria Cristina Figueiredo Silva tinha tomado conhecimento da MD, pois ela já havia me enviado há tempos um trabalho dela com João Costa sobre variação de sistemas verbais no português. Nós duas pleiteamos juntas, e conseguimos, da Diretoria da Abralin de 2007, que naquele biênio estava em Belo Horizonte, que escolhessem como um dos Conferencistas Visitantes, para o Encontro Nacional da Anpoll, mais uma vez, a linguista Heidi Harley. Ela aceitou, e teve sucesso em Belo Horizonte, com o minicurso e a palestra que deu sobre The bipartite structure of verbs cross-linguistically, no dia 1 de março de 2007. Naquele ano, foi uma patota grande de alunos da UFRJ para Belo Horizonte, para ouvirem essa heroína da MD. Depois, ela veio ao Rio e deu uma palestra na Faculdade de Letras.

As três diferenças radicais entre o modelo da MD e o modelo minimalista de Chomsky enumeradas por Halle e Marantz em Some Key Feartures of Distributed Morphology são late insertion (inserção lexical posterior à sintaxe), syntax all the way down (sintaxe descendo até dentro das palavras) e underspecification (possível especificação de peças vocabulares menor do que a especificação de traços provenientes da derivação sintática). Na minha percepção pessoal, a ideia de serem as raízes desprovidas de classificação lexical, a de que existe um princípio restritor da formação de idiomaticidade e a possibilidade de distinguir na leitura semântica uma parte proveniente da pura configuração sintática e outra proveniente de magras contribuições da raiz mereceriam ser incluídas na enumeração das particularidades do modelo gramatical da MD por seus autores. Inegavelmente, o mundo mudou, mas não para todos. (Mas isso talvez seja o que acontece para toda a história do saber). Hagit Borer vai mais longe ainda na separação entre significado produzido pela álgebra da configuração das peças funcionais e a contribuição 'maneira' da raiz.

O mundo está mudando, e neste novo mundo, não sei bem por quê, podemos tomar parte ativa. Quando a orquestra se faz ver, você ensaia suas próprias partituras... Na edição inaugural da revista LinguíStica, do Programa de Pós-graduação em Linguística da UFRJ (junho, 2005) apareceram os três primeiros frutos impressos do meu emprego da MD como ferramenta de trabalho: um artigo meu intitulado Mudanças sintáticas e sufixos latinos; um de Aniela Improta França, intitulado $O$ léxico mental em ação: muitas tarefas em 
poucos segundos, derivado de sua tese doutoral, a primeira que orientei com o sustento teórico da MD, defendida em 2002, e um de Aleria Cavalcante Lage, proveniente de sua tese doutoral, defendida em 2005, a segunda orientação de doutorado que fiz com base na MD, intitulada Concatenaçôes do objeto e do sujeito em português e em alemão: conclusôes de experimentos psicolinguísticos on-line.

$\mathrm{O}$ que me estimulou a orientar investigaçôes linguísticas com uso de metodologia neurolinguística foi o exemplo de três linguistas que fazem experimentação neurolinguística alicerçados em teoria linguística: Yosef Grodzinsky, Alec Marantz e Liina Pylkkanen. Os artigos das 'meninas', ambas, hoje, docentes concursadas na UFRJ, descrevem experimentos neurolinguísticos destinados a capturar eventos de reconhecimento lexical e computação bottomup, respectivamente. Pouco mais tarde, uma nuvem negra se formou quando percebi que introduções aceitáveis para submissão de artigo em journal de neurolinguística devem começar mais ou menos assim: It is believed that... e no espaço de uma linha e meia, no máximo, dê-se uma colocação simplória da crença linguística da plebe ignara. Citar linguista na bibliografia periga de pôr em risco o aceite, uma vez que o sonho do pioneirismo é primordial nessa área. The end.

Em meu artigo na revista Linguística 1, sobre sufixos latinos em verbos, analiso as palavras etimologicamente formadas com as raizes $\sqrt{ }$ fac-, $\sqrt{ }$ trac-, $\sqrt{ }$ ven-e $\sqrt{ }$ vert-, as antepassadas de fazer, trazer, vir e verter. O que tento fazer é decidir em que casos podemos dizer que os falantes de português fatiam as palavras de maneira semelhante aos fatiamentos que se faziam nos étimos do latim e em que casos as antigas raízes não são mais tomadas por nós, hoje, como elementos morfológicos, mas são somente resquícios da fonologia de um estágio passado. A lição a depreender na comparação entre latim e português é que as crianças podem captar os dados primários de sua comunidade de maneira ligeiramente diferente daquela atingida pela geração dos falantes mais velhos no que diz respeito a recortes sintáticos no interior de unidades frasais e também no interior de constituintes lexicais complexos. Ou seja, continuamente, na história, segmentos organizados sintaticamente e lidos por meio de semântica composicional por uma comunidade linguística podem ser computados de outro modo por falantes recém-chegados. Eles os lerão como uma peça única, de sintaxe achatada, e semântica arbitrária.

Na XXIII Reunião Anual da Anpoll, realizada em 2008 na UF de Goiás, apresentei no GT-TG um trabalho gestado em anos de preparação de aulas: Arbitrariedade saussureana, saltos e sobressaltos. Discuto aí exemplos para ilustrar 
as noções de raízes e afixos, semântica composicional e semântica arbitrária, chamando de 'saltos' mudanças de classe lexical que acarretam operações semânticas regulares, como nos pares trabalhar-trabalhador, rico-enriquecer, poder-poderoso, velho-velhice. Os 'sobressaltos' são causados por relações semânticas idiossincrásicas entre pares de palavras contendo partes morfológicas idênticas, como em restaurar-restaurante, Bahia-baianada, fogo-fogoso, trançatrancinha, bola-bolar, furo-furar. O que há de importante nos sobressaltos é que a idiomaticidade não incide na primeira camada de concatenação de raiz com categorizador, mas na segunda ou ainda depois. Marantz acredita que somente na primeira categorização é que pode incidir a arbitrariedade saussureana. Discordando dele, numa visão compatível com os sobressaltos está Hagit Borer, que mostra como em qualquer ponto de recategorização gramaticalmente possível de uma palavra pode incidir a 'encyclopedic search', a busca da enciclopédia, ou, por outro ângulo, a formação de uma unidade formalmente apropriada para ter significado idiomático.

Com a orientanda Cristina Siaines de Castro, que defendeu seu doutorado na UFRJ em 2007, com a tese intitulada Composicionalidade semântica em Libras: fronteiras e encaixes, pudemos perceber que a consciência aguçada da modularidade miúda que advém da MD é utilíssima para um ouvinte que queira conhecer a LIBRAS, pois fica natural fatiar separadamente aspectos simultâneos de um sinal se o modelo teórico já te faz esperar enfeixamentos independentes de diferentes propriedades de um sinal. Desembrulhar o pacotinho é mais fácil para quem já sabe que pacotes podem ser mais (línguas faladas) ou menos linearizados (línguas de sinais). A tese de Cristina Siaines de Castro foi adaptada para artigo por nós depois da defesa, e o artigo está publicado com o título Composicionalidade semântica em LSB-fronteiras e encaixes, em Salles e Naves (2010).

Continuamos, a Cristina Castro e eu, a estudar juntas até bem depois da defesa de tese dela e, entrando no tema da estrutura argumental, fizemos em coautoria uma comunicação intitulada Polissemias em verbos segundo uma abordagem exo-esqueletal, apresentada na $24^{a}$ Reunião Anual da Anpoll de 2009 (Brasília), cujo texto saiu publicado em Naves e Salles (2011). Quero destacar aqui que, para o tema 'estrutura argumental', a teoria de Hagit Borer se mostra a melhor, em face da polissemia surpreendentemente variada que se descobre ao examinar com detalhe a variação semântica dos verbos. Para esse evento / artigo escolhemos apenas quatro verbos para apresentar: correr, sofrer, bater, pegar. Aprendemos aí a dissecar a estrutura sintática, depreendendo duas partes 
distintas no significado, uma somente a partir da configuração e peças funcionais e outra dada pelo componente maneira a partir da raiz, conforme pleiteia Borer na teoria exo-esqueletal que está construindo.

Particípios passados são um tema interessante para se pesquisar dentro do arcabouço da $\mathrm{MD}$, porque apresentam formas regulares e irregulares em relação às formas do infinitivo, entram na composição de tempos compostos (tenho viajado), adjetivos (safado), nomes (chiado, delegado), advérbios (enrolado), infinitivos derivados diacronicamente de particípios passados (fritar, receitar, discursar), e os significados dos compostos podem ser tanto arbitrários como composicionais. Eu tive muito proveito no estudo da MD com o artigo de Ippolito (1999), que eu tinha no meu arsenal, e estava ansiosa para trabalhar no tema em cima de dados do português. No ano 2002, entrou na pós-graduação em Linguística da UFRJ um estudante inteligente proveniente da matemática, Alessandro Boechat de Medeiros, e sem fazer alarde fui logo imaginando que ele poderia ser um valente desbravador dos nossos caminhos pela MD a partir desse tema. Vestindo a camisa, ele aceitou o tema e trabalhou criativamente nos particípios em sua pesquisa para o Mestrado, obtido em 2004 com a dissertação intitulada Sintaxe e semântica do Particípio Passado. Seguindo para o Doutorado, estagiou com Marantz na sua bolsa sanduíche, e defendeu um excelente estudo dos particípios como tese doutoral, intitulado Traços Morfossintáticos e Subespecificação Morfológica na Gramática do Português: Um Estudo das Formas Participiais. Com essa bagagem, pôde ser convidado para fazer seu pós-doutorado na USP, instaurando, assim, uma ponte interessante entre as nossas pós-graduações.

A MD acabou vindo a ser, para mim, uma mina de ideias. Da interface com a literatura saiu uma pesquisa que está se mostrando muito gratificante: a criação de neologismos por escritores. De onde saem as invencionices lexicais do nosso Guimarães Rosa? O estudante Everton Lourenço entrou na nossa pósgraduação em 2009 e obteve o seu título de Mestre em 2011 com uma dissertação intitulada Estudo do mecanismo de criação neológica na obra de Guimarães Rosa, um tema que estava aguardando pela chegada dele na nossa pós. Esse estudo só foi possível porque existia um outro estudo anterior, da professora da USP Nilce Sant'Anna Martins, publicado pela Editora Edusp em 2001, O léxico de Guimarães Rosa. A pesquisadora dá a localização de todas as fontes possíveis de peças vocabulares que o escritor pudesse conhecer, desde a literatura medieval até a moderna do português europeu. As palavras não localizadas em dicionários ou fontes literárias foram marcadas pela pesquisadora como sendo as criadas pelo 
escritor. Em cima desse último conjunto trabalhou o Everton, a partir de uma hipótese que somente poderia ser explorada em dissertação de gramática gerativa graças ao conhecimento do princípio da 'sintaxe até lá embaixo': o escritor não criaria novas raízes, mas, sim, novas combinaçóes entre raízes existentes e peças funcionais também existentes no repertório lexical do português, fazendo uso das mesmas regras sintáticas da gramática. Foi justamente esse o resultado do estudo. Um aspecto fascinante dessa conclusão é que o escritor foi um grande observador da morfologia das palavras, pois, como mostrou em sua dissertação o Everton Lourenço, praticamente todos os padrões sintáticos dos sufixos mais usados na formação de palavras foram utilizados em suas numerosíssimas combinações inesperadas, porém perfeitamente decodificáveis pelo leitor, ainda que pego de surpresa.

Atualmente, estou orientando uma recém-mestranda, a Rejane Neves, que oriento desde o seu segundo ano de graduação, em 2009, na Iniciação Científica. A Rejane coletou palavras do português europeu estranhas para nós brasileiros, para vermos que diferenças eram essas diferenças lexicais entre o português do Brasil e o português europeu. A pesquisa deu no que a MD prevê: ou são novas combinações de raiz mais sufixo, ou são diferentes leituras da mesma estrutura sintática. Por exemplo, em português europeu os professores aliciam seus alunos, porque isso significa 'animá-los para uma coisa boa', e não má. Notem que a etimologia dessa palavra é pela raiz do verbo impessoal licet, 'ser permitido' e, portanto, quem adicionou malícia em aliciar fomos nós brasileiros! Para a dissertação de Mestrado da Rejane, haverá uma excursão por escritores africanos que escrevem em português, e já temos uma lista fascinante de criaçôes lexicais dos escritores Mia Couto e Ndjake. Essas criações não seriam possíveis se não fossem sintáticas, e se eles não soubessem, instintivamente, que a sintaxe vai até lá embaixo.

Em 2011, obteve o título de Mestre minha orientanda Heloísa Macedo Coelho com a apresentação de uma dissertação sobre Correspondências entre sufixos em palavras complexas: um levantamento em quatro línguas românicas. $\mathrm{O}$ objetivo do estudo era testar a 'sintaticidade' de palavras. Se as palavras fossem um todo inteiriço que é selecionado de uma numeração para entrar em uso na inserção lexical, então quatro línguas românicas postas em confronto deveriam carregar suas mochilas lexicais ou porta-numeração de maneira bastante uniforme. O levantamento feito por Heloísa Coelho foi grande e trabalhoso: selecionamos um número considerável de sufixos categorizadores de nome, 
adjetivo e verbo, e a Heloísa pesquisou em muitas palavras para cada sufixo correspondências nas quatro línguas que fossem as traduções de uma palavra em português com um dado sufixo, por exemplo, tratamento, felicidade, abertura, corajoso, empobrecer, americanizar... A conclusão desse survey foi a seguinte: as línguas românicas, mesmo sendo filhas de uma mesma língua-mãe, não mostraram correspondências regulares em todas as palavras. Pudemos notar os seguintes tipos de combinações:

a. cada língua apresenta a mesma raiz e o mesmo sufixo;

b. as quatro línguas coincidem na raiz mas escolhem diferentes prefixos e / ou sufixos;

c. um subconjunto das línguas compartilham a mesma raiz; e

d. cada língua faz uso de uma raiz diferente para codificar o mesmo significado.

A conclusão é que os exemplos confirmam a hipótese de que não existe como lista um léxico pronto, mas, sim, há a continuação da sintaxe all the way down, formada por concatenaçôes de pedaços menores, os morfemas, tal como prevê a teoria da MD.

Com um estudo sobre 'falsos cognatos' entre francês e português, recebeu o grau de Mestre em 2011 a minha orientanda Karine Vieira, que iniciou o seu Mestrado em 2008. Como se pode explicar que entre línguas parentes se formem divergências lexicais, por exemplo, nos pares dados a seguir na ordem portuguêsfrancês (com as traduções de cada um em inglês, usado como meta-linguagem): atender (attend) - attendre (wait for); amassar (smash) - amasser (put together in disorder); apelar (appeal with false arguments) - appeler (call); apontar (point to) - apponter (land); aprender (learn) - apprendre (teach); realizar (make) - réaliser (realize). Como acontecem essas divergências semânticas? Para desenvolver a explicação sobre a formação de falsos cognatos, percebi que seria mais explanatório tomar base teórica em Hagit Borer em vez de perseverar em Alec Marantz, porque a teoria dela assume pura e simplesmente 'maneira' como o componente semântico de uma raiz, com 'adição de modificador' como a operação semântica que modifica o significado proveniente da pura configuração sintática e suas peças funcionais. A comparação dos significados dos pares de cognatos mostra que na diferença da maneira do evento está a essência da diferença entre os significados em cada língua. Os dois artigos de Hagit Borer que nos deram a base teórica nessa investigação foram Borer (2004) e Borer (2009). 
Isabella Lopes Pederneira apresentou o trabalho Etimologia e reanálise de palavras em sua dissertação de Mestrado, defendida em 2010. O objetivo do estudo era saber que relação existe entre a etimologia de uma palavra e a sua análise morfológica no estágio atual da língua, ou seja, para os falantes atuais. Dois conjuntos de mudanças diacrônicas foram estudados: particípios passados e verbos com prefixos. Quanto aos particípios passados, foi visto que há verbos derivados de particípios passados cujos infinitivos ainda existem, como no conjunto receptar, derivado do particípio passado de recipere, que dá origem a receber; e verbos derivados de particípios passados de verbos que caíram em desuso, como misturar, que vem de mistus, o particípio passado de miscere que não existe mais. Os verbos com prefixos podem receber um olhar semelhante: há prefixos que todos percebem, como em engaiolar, e prefixos que já passam desapercebidos, como em decidir. A metodologia do trabalho foi experimental, com aplicação de testes de questionário e testes de priming com decisão lexical. A questão trabalhada era distinguir, entre os verbos formados a partir de particípios passados, aqueles que os falantes ainda reconhecem como relacionados ao infinitivo do particípio passado que virou parte do novo verbo; $\mathrm{e}$, no caso dos verbos com prefixo, descobrir em quais os falantes ainda reconhecem o prefixo e em quais não fazem a segmentação de prefixo. O que se concluiu em ambos os casos foi que o reconhecimento pelos falantes do relacionamento entre duas palavras supostamente relacionadas só é constatado nos testes quando os falantes conhecem o infinitivo do verbo, seja regular ou irregular o particípio passado, e quando conhecem a peça lexical juntada ao prefixo. Ou seja, o falante tem que reconhecer ambas as peças de uma palavra prefixada para analisála como morfologicamente complexa; se uma raiz cai em desuso, o verbo antigamente percebido como prefixado está agora sendo lido como possuidor de uma raiz fonologicamente ampliada. As relações etimológicas são percebidas como se fossem relações entre duas palavras sem qualquer relação morfológica. Por exemplo, em decidir as pessoas não veem o prefixo de- e também não veem relação alguma entre decidir e cadente.

Atualmente a Isabella está se armando para produzir uma tese doutoral sobre estrutura argumental. Estamos estudando polissemias em verbos no português e também comparando verbos em português e italiano. As polissemias são muitas, e estamos, por isso, mais uma vez, considerando que a teoria de Hagit Borer se presta melhor do que a de Marantz para descrever o que estamos vendo. Já estão quase prontas as malas da Isabella para o doutorado sanduíche no Queen Mary College da London University. 


\subsection{Depoimento de Alessandro Boechat de Medeiros, professor adjunto do Departamento de Linguística e Filologia da UFRJ}

Comecei meu mestrado em linguística em 2002. Num dos primeiros cursos que fiz, de Introdução à gramática gerativa, tomei contato com a MD, com a professora Miriam Lemle, do Departamento de Linguística e Filologia da UFRJ. Naquela época, eu, que vinha de uma espécie de universo paralelo - tinha um bacharelado em matemática e estava terminando uma licenciatura também em matemática -, ainda me familiarizava com a teoria da regência e da vinculação (o modelo GB), através dos calhamaços introdutórios de Lilianne Haegeman e Eduardo Raposo. No curso da professora Miriam Lemle, trabalhamos dois textos importantíssimos (e bastante difíceis): Remarks on Nominalization, de Noam Chomsky (CHOMSKY, 1970), considerado por muitos o texto fundador do lexicalismo, e No Escape from Syntax: Don't Try Morphological Analysis in the Privacy of your Own Lexicon, de Alec Marantz (MARANTZ, 1997), que, além de propor soluções sintáticas para problemas levantados no próprio Remarks, fazia uma releitura desse texto, afirmando que, de fato, derrubava - e não fundava - o lexicalismo.

Apesar de ainda ser bastante ignorante em tudo, fiquei muito entusiasmado com aquela maneira de ver as coisas. A ideia de que raízes não possuem categoria (não são nominais, nem verbais, nem adjetivas, etc.), de que ganham sua categoria no contexto sintático em que ocorrem, proposta no texto No Escape from Syntax, e o fato de, com a MD, nos livrarmos das dificuldades associadas à distinção entre morfologia derivacional e morfologia flexional, foram, na época, as características da teoria que mais me chamaram a atenção e que me deixaram interessado nela.

Também gostei do curso e da professora; e, no final daquele primeiro semestre de mestrado, eu, que não tinha orientador nem projeto ainda (naquela época era possível entrar no mestrado assim, desde que você passasse nas provas de conteúdo específico e de inglês instrumental), procurei a professora Miriam Lemle e perguntei a ela se me aceitaria como seu orientando. E ela aceitou me orientar.

Contudo, ter-me interessado pela teoria e ter-me tornado orientando da professora Miriam Lemle não determinaram de imediato qual seria o tema de minha pesquisa, nem a teoria que adotaria para desenvolvê-la. Durante o primeiro ano de mestrado, me envolvi com o projeto de um amigo da engenharia: 
desenvolver um TTS (text-to-speech: programa de leitura automática de texto). Ele precisava de um linguista para que sua pesquisa de mestrado andasse, e eu precisava de um projeto para tentar me tornar um linguista. Apesar dos nossos esforços, por conta de discordâncias que o meu amigo tinha com seu orientador, a pesquisa ficou empacada, e, temendo prejudicar o programa do qual eu participava com eventual atraso da minha defesa, pois eu era bolsista do $\mathrm{CNPq}$, desisti desse projeto no início de 2003 e parti para um trabalho teórico, com um tema proposto pela professora Miriam Lemle: estudar os particípios do português do Brasil. Na época, tive a sorte de poder frequentar, na UFRJ, um minicurso ministrado pela professora Heidi Harley, no Instituto da ABRALIN em março de 2003, que me ajudou a entender o espírito da coisa. Retornei à MD e confesso que fiquei bem mais feliz.

Defendi minha dissertação de mestrado em MD em fevereiro de 2004. A dissertação estudava propriedades do particípio passado em português e procurava dar uma explicação estrutural para as várias perguntas que a adoção do modelo teórico permitia fazer sobre o assunto. Por exemplo, há diferenças morfossintáticas entre particípios quando esses ocorrem em contextos sintáticos distintos (tempo verbal, adjetivos, nominalizações, voz passiva, etc.)? Se há diferenças morfossintáticas, como explicamos que muitas vezes a mesma forma ocorre nos diferentes contextos mencionados? Por que o argumento interno do verbo de que deriva o particípio é o argumento preservado quando um particípio passado é criado? As perguntas enumeradas mostram que formas como o particípio são um objeto de estudo interessante porque coloca questões nas interfaces entre distintos módulos da arquitetura da gramática, como as interfaces sintaxe-morfologia e sintaxe-semântica. E a MD, que assume que a sintaxe alcança a estrutura interna daquilo que o mainstream da teoria gerativa chama de unidade de nível zero da sintaxe (a palavra), oferece respostas interessantes para essas questóes, pois permite supor que estruturas sintáticas distintas subjazam às formas participiais em contextos sintáticos distintos - o que também dá conta de suas frequentemente distintas interpretações, distribuição e morfologia - e, ao mesmo tempo, permite entender por que uma mesma forma pode ocorrer nos diferentes contextos, por meio do conceito de subespecificação vocabular.

Antes mesmo de terminar o mestrado, fiz a seleção para o doutorado na UFRJ, no final do ano de 2003, e fui aprovado. A orientadora, obviamente, seria a mesma. Comecei o doutorado em março de 2004 e, durante os anos em que 
estive na condição de doutorando, conheci outras pessoas que também estavam trabalhando com o modelo aqui no Brasil, como a professora Ana Paula Scher (de quem, descobri depois, fora colega no minicurso ministrado pela professora Heidi Harley, no instituto da ABRALIN de 2003), da USP. Conhecemo-nos no primeiro Colóquio Internacional de Língua Portuguesa, realizado na UFSC, em 2004, onde também conheci a professora Maria Cristina Figueiredo Silva. No terceiro ano de doutorado (2006), trabalhei com o professor Alec Marantz, da NYU (New York University), quando fiz meu estágio de doutorado no exterior (bolsa PDEE - CAPES). O professor Marantz foi meu orientador nesse estágio fora do Brasil. O estágio no exterior foi importantíssimo para minha formação, por vários motivos, mas um em especial: aprendi a ler melhor. Na volta ao Brasil, ainda frequentei outro minicurso ministrado pela professora Heidi Harley, dessa vez no instituto da ABRALIN realizado na UFMG, em Belo Horizonte, no ano de 2007, do qual também tirei muito proveito.

Como muitas questões ficaram pendentes na dissertação de mestrado sem mencionar aquelas soluções que você já não considera tão boas logo após a defesa - a pesquisa de doutorado continuou tratando do particípio passado no português do Brasil (doravante $\mathrm{PB}$ ). Também incluí na tese um estudo das formas em -nte no $\mathrm{PB}$, que a gramática tradicional chama de particípio presente, interessado na sua seleção de argumento (do argumento externo do verbo que lhe serve de base) e em suas possíveis propriedades aspectuais - e em possíveis relações entre aspecto e a seleção do argumento. Nessa continuação do estudo dos particípios, começaram a se colocar mais claramente questôes relacionadas à estrutura argumental dos verbos. Por exemplo: de que maneira o conhecimento sobre as propriedades dos particípios pode ajudar na formulação de teorias sobre a estrutura argumental dos verbos? A tese abandonava a ideia tradicional de papel temático e tentava decompor os verbos em estruturas de evento sintaticamente representadas, seguindo propostas de diversos autores (entre eles, HALE; KEYSER, 2002; LIN, 2004; BORER, 2005; MARANTZ, 2006; RAMCHAND, 2008), levando em consideração propriedades acionais, sua morfologia e sua interação com aspecto e tempo verbal. Com uma ontologia para as raízes dos verbos da língua e para os itens funcionais que compóem a estrutura do sintagma verbal, seria possível: (1) propor configurações sintáticas específicas que explicassem a chamada seleção de argumentos e a contribuição desses na estrutura acional do sintagma verbal e (2) explicar por que certos verbos podem formar as chamadas passivas de estado alvo (KRATZER, 2000) ou passivas 
estativas (EMBICK, 2004), que são uma forma de particípio no português, e por que outros verbos não tão facilmente o fazem (se é que o fazem). Seria possível também explicar características de nominalizações derivadas de particípio, como as chamadas nominalizaçôes em -da (paulada, fervida), a partir de certas hipóteses, assumidas na tese, sobre como deve ser a estrutura argumental dos verbos que servem de base a tais nominalizaçôes.

Defendi meu doutorado (com ajuda das bolsas do CNPq, PDEE da CAPES e Aluno nota dez da FAPERJ) em fevereiro de 2008. A partir de junho do mesmo ano, trabalhei, com bolsa FAPESP, como pós-doutorando no Departamento de Linguística da USP por quase dois anos, sob a supervisão da professora Ana Paula Scher, me tornando membro do GREMD (Grupo de Estudos em Morfologia Distribuída), onde desenvolvi pesquisa sobre certos tipos de nominalizações de verbos, como as formadas pelos sufixos -nte e -dor (fertilizante e pensador, por exemplo), que denotam entidades interpretadas como sujeitos dos verbos de base, não os eventos associados a esses verbos (como nas nominalizações fertilização e pensamento). Esse tipo de pesquisa era complementar à pesquisa desenvolvida pela própria professora Ana Scher, que estudava, na época, justamente as nominalizaçôes que denotam eventos (como as últimas citadas acima). Aqui, mais uma vez a interação entre morfologia (tradicionalmente chamada de derivacional) e estrutura argumental / de eventos é investigada, com frutos interessantes. O período em que estive na USP foi importantíssimo para meu crescimento como linguista e como pesquisador, pois tive a oportunidade de conhecer linguistas e estudantes de vários outros estados, de trocar ideias com eles, e de melhorar minha reflexão sobre meus temas de pesquisa.

Em março de 2010, me tornei professor adjunto de linguística do Departamento de Linguística e Filologia da UFRJ. Atualmente, ministro o curso de Linguística III (sintaxe gerativa) na graduação em Letras e dou cursos na pósgraduação em Linguística. Faço parte da linha de pesquisa "gramática na teoria gerativa”, da pós-graduação em Linguística do meu departamento, e continuo sendo um membro externo do GREMD. Tenho dois alunos de iniciação científica, duas alunas de mestrado e cooriento, com a professora Márcia Dâmaso, um aluno de doutorado. As pesquisas que meus alunos e eu temos desenvolvido seguem o arcabouço teórico da MD. Quanto aos meus temas de pesquisa atuais, todos giram, desde o meu doutorado, em torno de questóes relacionadas à estrutura argumental associada aos verbos e outros itens. $\mathrm{O}$ próprio projeto que registrei na base SIGMA da UFRJ, de cujo texto aproveito 
algumas partes no que segue, trata de estrutura argumental e das suas possíveis interaçôes com estruturas morfossintáticas.

De fato, a descrição e compreensão da estrutura argumental de verbos e outras classes de palavras é, atualmente, um dos problemas mais importantes para a linguística formal. Grosso modo, podemos dizer que a literatura apresenta dois tipos de tratamento para a questão: (a) teorias nas quais o léxico idiossincraticamente especifica para os itens o número e os tipos de papéis (temáticos ou aspectuais) a serem atribuídos a seus argumentos (STOWELL, 1981; CHOMSKY, 1981; TENNY, 1992); (b) teorias nas quais as seleçóes de argumentos dos verbos podem ser explicadas por algum tipo de decomposição, sintática ou semântica (lexical), em subpredicados ou estruturas de eventos que atribuem papéis (temáticos ou aspectuais) aos seus argumentos (HALE; KEYSER 2002; LEVIN; RAPPAPORT, 1995; RAMCHAND, 2008; MARANTZ, 2006; BORER, 2005, entre outros). No meu entendimento, teorias do primeiro tipo não fazem mais do que listar idiossincrasias lexicais sem explicar por que as coisas são como são. Em particular, não explicam como mudanças categoriais (de classe de palavra) afetam a estrutura de argumentos associada à raiz ou ao radical que serve de base para tal mudança, nem a recorrência de certas formas associadas a certas propriedades argumentais dos itens que as possuem (por exemplo, a presença de prefixos e a obrigatoriedade de argumentos internos nos verbos que os trazem). Teorias do segundo tipo, por outro lado, nos permitem entender diversas regularidades entre itens e fornecem meios de compreender como mudanças categoriais e a presença de determinados prefixos criam ou alteram a estrutura argumental.

$\mathrm{Na}$ minha pesquisa, usando o arcabouço teórico da MD, assumo que estrutura argumental é estrutura de eventos e que essa estrutura pode e deve ser representada, pelo menos em parte, sintaticamente. A pesquisa se estrutura, pois, em torno de três coisas: (a) propor estruturas sintáticas que representem estruturas de eventos de verbos e outras categorias, e que expliquem, sem a necessidade de regras de link ou hierarquias temáticas (como as de FILLMORE, 1968 e JACKENDOFF, 1990, entre outros), por que determinado número de argumentos está tipicamente associado a um item, por que os argumentos selecionados são de determinado tipo (semântico) e não de outro, por que ocupam a posição que ocupam na sintaxe e como contribuem na interpretação aspectual ou acional da eventualidade denotada; (b) estabelecer uma classificação ou ontologia das raízes de verbos e outros itens, entendendo que propriedades 
semânticas devem ter para que sejam licenciadas em uma ou mais estruturas de eventos; (c) entender como afixos tradicionalmente ligados à morfologia derivacional se associam à estrutura de eventos (argumental) dos itens em que ocorrem e que contribuiçóes exatamente dão, quando for o caso, para sua interpretação.

Ora, uma vez que representamos estruturas de eventos em termos de estruturas sintáticas, e que estruturas sintáticas são hierárquicas, é possível imaginar que um morfema que ocupe determinada posição nessa hierarquia tenha escopo sobre certa parte da estrutura de eventos, mas não sobre outra, hierarquicamente mais alta; isso explicaria, entre outras coisas, por que certos prefixos podem ocorrer em alguns verbos, mas não em outros, ou por que uma nominalização de um verbo (envolvendo, por exemplo, os sufixos - $d a$, -ção, mento, $-i a$, etc.) mantém certos argumentos, mas não outros, do verbo que lhe serve de base. Ou seja, a própria investigação sobre a estrutura morfossintática de palavras complexas pode trazer evidências a favor ou contra determinadas hipóteses sobre como devem ser as estruturas de evento tipicamente encontradas nas línguas, em particular na língua portuguesa. Por outro lado, uma boa teoria de estrutura de evento (argumental) pode nos dar elementos para entender não só como deve ser a morfossintaxe de palavras complexas mas também que interpretação poderíamos atribuir aos itens funcionais (morfemas) envolvidos.

Um exemplo disso é o tratamento que procurei dar para o prefixo des(MEDEIROS, 2010) em português, inspirado em hipóteses sobre a interação entre estrutura argumental dos verbos e o prefixo re-do inglês, encontradas em Marantz (2006). Um fato observado na pesquisa é que esse prefixo ocorre somente em verbos cuja interpretação envolve aquilo que Parsons (1990) chama de estado alvo (por exemplo, o estado descrito pela palavra preso, associado ao verbo prender); além disso, o prefixo modifica somente tal estado, não o evento inteiro. Em desenterrar, por exemplo, existe um estado, 'enterrado', ou 'totalmente coberto por algo', que é o alvo do evento de enterrar. Quando desenterramos raízes de árvores, modificamos seu estado (o de estar todo coberto por algo, como a terra), invertendo-o ou negando-o, não o evento de enterrá-las, que provavelmente nunca aconteceu. Supondo que o verbo enterrar encerra uma estrutura sintática em que há uma atividade causadora e um estado alvo dessa atividade, que há morfemas diferentes para introduzir um e outro, e que tais morfemas estão hierarquicamente relacionados, com o introdutor da atividade causadora mais alto que o introdutor do estado alvo, explicamos de maneira 
elegante porque somente tais verbos aceitam o prefixo e usamos a noção de escopo de negação para explicar como o prefixo entra na composição do significado de desenterrar: o prefixo tem escopo bem restrito, somente sobre a parte da estrutura que denota o estado alvo da atividade de enterrar. Assim, a preferência do prefixo des- por estados mostra que eventos denotados por verbos como enterrar são complexos, o que sugere que uma abordagem por estrutura de evento é promissora. Ao mesmo tempo, com essa abordagem, conseguimos entender melhor como se distribui o prefixo des-, identificamos uma interpretação única (negação ou inversão de estado), que pode explicar sua ocorrência em outras categorias (nomes e adjetivos que denotam estados), e podemos estender a abordagem para outros prefixos com interpretação semelhante, como o prefixo re-(MEDEIROS, 2012).

O tema "estrutura argumental", pois, acaba sendo onipresente. E creio que o estudo sistemático de várias classes de palavras morfologicamente complexas possa fornecer elementos para que entendamos não só as propriedades morfológicas dessas palavras como também suas seleçōes de argumentos e propriedades semânticas importantes envolvidas. Defini, portanto, algumas frentes de pesquisa que venho desenvolvendo com meus alunos.

Uma delas é estudar nominalizaçôes de verbos com interpretação eventiva, como as que trazem os sufixos -mento, -ção, -da, etc. Em geral, tais nominalizaçōes licenciam somente a ocorrência dos argumentos internos de seus verbos de base (ALEXIADOU, 2001), ainda que possam apresentar propriedades de controle em relação ao argumento externo. Qual é a relação entre a estrutura morfossintática da nominalização e a estrutura de eventos associada aos seus possíveis verbos de base? Existem diferenças morfossintáticas ou semânticas subjacentes às nominalizaçōes com os afixos -mento, -ção, - $d a$, etc., ou esses são meras realizações fonológicas distintas de um mesmo morfema abstrato nominalizador, ocorrendo em estruturas morfossintáticas idênticas? Outra é estudar as nominalizações de verbos que denotam entidades que são lidas como sujeitos de seus verbos de base (as terminadas em -nte e-dor, por exemplo). Observe-se que, assumindo que o argumento externo do verbo é sintaticamente relacionado ao verbo (como defendido por diversos autores; por exemplo, CHOMSKY, 1995; KRATZER, 1996; PYLKKÄNEN, 2002), talvez seja mais natural tratar tais casos sintaticamente, não postulando operaçōes lexicais que criam essas formas no léxico. Uma terceira frente é estudar verbos derivados de adjetivos (entortar), tentando entender de que maneira o adjetivo pode participar da estrutura de eventos do verbo, e 
adjetivos derivados de verbos (comovente), tentando entender o que ocorre na estrutura de evento do verbo de base quando o adjetivo é gerado. A quarta frente é estudar como prefixos (como en-, a-, es-, etc., presentes em verbos como engavetar, aterrar, esfaquear) criam verbos a partir de bases nominais ou adjetivas: que tipo de contribuição para a estrutura de eventos do verbo gerado estão dando? Criam predicações a partir de bases nominais (PESETSKY, 1995; HALE; KEYSER, 1993, 2002; MARANTZ, 2006; PYLKKÄNEN, 2002)? No caso dos prefixos, é importante ainda fazer a diferença entre aqueles que aparentemente funcionam como advérbios e aqueles que funcionam introduzindo argumentos (MEDEIROS, 2010). Exemplos dos últimos são os discutidos acima; exemplos dos primeiros são des-, de negação, e re-, de repetição. Por fim, como já mencionei anteriormente, é preciso entender como a semântica das raízes pode estar interagindo com as estruturas de evento propostas, o que explicaria sua distribuição - ou seja, elaborar uma sua ontologia (MARANTZ, 2003; HARLEY em vários artigos, MEDEIROS, 2008; SCHER; MEDEIROS; MINUSSI, 2012; LEVINSON, 2007). Existem ainda muitas outras questôes que não estão enumeradas aqui, e que pertencem a várias dessas frentes ao mesmo tempo; também vale mencionar que, à medida que a pesquisa avança, novas frentes se abrem, criando uma rede cada vez mais complexa e interessante, com questões próprias, que exigem novas iniciativas de pesquisa.

Como ainda estou em início de carreira como professor da UFRJ, tenho poucos alunos, mas gostaria de dizer, neste parágrafo, o que eles estão fazendo em suas pesquisas. No momento, minhas alunas de mestrado estão às voltas com dois tipos de verbos: uma delas estuda as propriedades sintáticas, semânticas e morfológicas dos verbos psicológicos do tipo objeto experienciador; outra estuda os verbos do tipo location / locatum (HALE; KEYSER, 1993, 2002). Um dos meus alunos de iniciação científica está investigando o prefixo es- (em verbos como es-faqu-ear); minha outra aluna trabalhou durante o ano de $2011 \mathrm{com}$ nominalizações em -ada denominais (pedr-ada). O aluno de doutorado que eu e a professora Márcia Dâmaso orientamos estuda clíticos em Kayabí.

Evidentemente, muitos dos temas enumerados nos parágrafos anteriores vêm sendo investigados por outros pesquisadores que seguem outros modelos teóricos e mesmo por colegas que trabalham com MD. Meu interesse em pesquisar estrutura argumental é compartilhado, por exemplo, com a professora Miriam Lemle e seus orientandos e com a professora Ana Paula Scher e os membros do GREMD, muitos deles seus orientandos. São pesquisas paralelas 
que, contrariando o postulado das paralelas, se encontram em vários pontos. Com a professora Ana Scher compartilho o interesse pelas nominalizaçōes de verbos, como já mencionei acima. O estudo de prefixos e suas relaçôes com verbos denominais também vem sendo desenvolvido por uma aluna da professora Ana Scher, Indaiá Bassani, com muitos resultados interessantes.

Terminando, gostaria de dizer que as perguntas que hoje tento responder são possíveis em grande parte por conta do modelo que adoto em minha pesquisa, a MD. Sem ele, creio que não me teria ocorrido nem a metade das questões colocadas (e não colocadas) aqui neste pequeno texto, e não teria tantos temas interessantes de pesquisa.

\subsection{Morfologia Distribuída na Universidade de Säo Paulo: Depoimento de Ana Paula Scher, professora doutora do Departamento de Linguística da Universidade de São Paulo}

Esta seção trará uma breve apresentação de como o modelo da MD vem sendo utilizado como o quadro teórico dentro do qual meus alunos da Universidade de São Paulo, de graduação e de Pós-graduação, além de mim mesma, desenvolvemos trabalhos que tratam, formalmente, de aspectos morfofonológicos e morfossintáticos de línguas como o PB, o hebraico, o georgiano e o japonês.

\section{A opção pela Morfologia Distribuída}

Meu interesse pelas pesquisas desenvolvidas a partir da perspectiva da MD começou ainda durante a elaboração de minha tese de doutorado intitulada " $A s$ Construçôes com o Verbo Leve DAR e Nominalizaçôes em -ada no PB”, defendida em fevereiro de 2004. Esse trabalho procurava investigar um tipo bem específico de construçôes com verbo leve (CVLs), em que dois elementos - o verbo dar e uma nominalização em -ada, tal como em O João deu uma olhada no nenê predicam como se fossem um só, projetando uma estrutura sintática monooracional.

Entre outras questôes, ao desenvolver o projeto de doutorado, procurei determinar o processo gramatical responsável pela formação desse tipo de CVLs. Mais especificamente, era importante apontar em que componente da gramática, o léxico ou a sintaxe, são derivadas essas formações. Essa questão aparece constantemente nos trabalhos sobre as CVLs em línguas como inglês (CAMPBELL, 
1989), o japonês (GRIMSHAW; MESTER, 1988; DUBINSKY, 1997), entre outras, e as respostas apresentadas dividem os autores entre aqueles que têm uma orientação lexicalista, sugerindo que a formação da CVL se dá no léxico, e os que defendem que estas construçóes são produzidas por operações sintáticas. Os dados que eu examinava apontavam para a adequação de uma análise sintática para a formação das CVLs, em detrimento de uma análise lexical. Entre outros fatores, de um ponto de vista mais tradicional, as CVLs se distanciavam bastante das expressões idiomáticas, que podem receber um tratamento mais lexical, na medida em que é possível dizer que as primeiras constroem seu significado de forma bastante composicional, ao contrário das últimas.

Era importante, ainda, responder a seguinte questão: como se formam os elementos integrantes de uma CVL com dar? Em especial, eu estava interessada em entender e explicitar o processo pelo qual se forma a nominalização dessas construções. A comparação entre uma CVLs como (1), em que a presença do verbo intransitivo remar parece evidente na estrutura da nominalização remada, e outra como (2), em que é o nome remo que parece derivar a nominalização remada, foi crucial para minha opção de usar um modelo não lexicalista, como a $\mathrm{MD}$, como modelo teórico para fundamentar a análise sintática que eu desenvolveria para esses tipos de nominalizações em minha dissertação.

(1) O João deu uma remada para se afastar da margem.

(2) O João deu uma remada no ladrão (para se defender).

Nas duas sentenças acima, nominalizaçôes foneticamente idênticas ocorrem nas CVLs que recebem interpretaçôes diferentes em cada caso. No primeiro caso, atribui-se à CVL uma leitura de eventualidade diminutivizada, com a nominalização remada expressando um processo. que não se verifica no segundo caso. A interpretação mais evidente para a sentença em (2) é a de que o João atingiu o ladrão com um remo, com a nominalização remada, em particular, apresentando uma leitura de resultado.

Depois de examinar, a partir de Grimshaw (1990), a capacidade que as nominalizações em -ada têm para determinar (ou não) uma estrutura argumental, pude atestar o comportamento ambíguo de muitas delas a esse respeito. No entanto, seu comportamento como nominalização de processo parecia bastante sistemático. Era necessário, de qualquer maneira, responder às seguintes questões: 
i) Como se formam as nominalizações em -ada de (1) e (2)?

ii) Pode-se dizer que, em (1), parte-se da derivação do verbo remar, com todas as suas projeçōes funcionais, para derivar remada, enquanto que, em (2), é necessário que primeiro tenha sido formado o nome remo?

iii) Pode-se dizer, alternativamente, que, nos dois casos, a derivação parte de um mesmo ponto, a raiz, e se constitui de categorias distintas, expressas por projeções funcionais diversas, resultando em termos distintos, com significados distintos?

A partir daí, com base em Alexiadou (2001), observei que, tão importante como a possibilidade de determinar ou não uma estrutura argumental, era perceber que as nominalizações são diferentes por causa da estrutura em que estão inseridas. Para dar conta dessa diferença, enfatizei o papel crucial que as categorias funcionais presentes na derivação das nominalizações de cada tipo de CVLs desempenham na determinação de sua interpretação: uma projeção aspectual, por exemplo, estará presente na derivação para a qual uma leitura de diminutivização pode ser atribuída, mas não na derivação da nominalização que não será interpretada como diminutivizada.

Assim, propus que a diferença entre as leituras de processo ou resultado que pude observar que as diferentes nominalizações em - ada do PB resultam de configurações sintáticas distintas: as que admitem leitura de processo apresentam, em sua representação, um conjunto de categorias funcionais associadas a sintagmas verbais, que resultam nessa leitura. $\mathrm{O}$ mesmo não ocorre com as nominalizaçōes de resultado. As propriedades de evento, ou processo de uma nominalização, então, se devem ao conjunto de nós funcionais na estrutura dessa nominalização, que serão, necessariamente, dependentes dos nós previamente especificados nas categorias de verbo e nome de que derivavam.

Assim, exemplos como os que se têm em (1) e (2), além de outros como (3), permitiram que se levantasse a hipótese de que as nominalizações em -ada podem resultar de três estruturas distintas.

(3) O João deu uma parafusada mais apertada nesses três parafusos que sustentam a estrutura.

A discussão para se chegar a essa proposta se baseou em Arad (2003), que sugere, seguindo Kiparsky (1982), que os verbos do inglês que se relacionam com nomes por meio de um morfema zero não formam um grupo uniforme: 
tanto podem derivar diretamente da raiz, como hammer (martelar), quanto podem derivar do próprio nome correspondente, como chain (acorrentar) (cf. (4) e (5)). Em outros termos, esses verbos estabelecem relações diferentes com os nomes com os quais se relacionam por meio do morfema zero.

(4) He hammered the nail with a rock (ARAD, 2003).

Ele martelou o prego com uma pedra.

(5) *They chained the prisoner with a rope (KIPARSKY, 1982).

Eles acorrentaram o prisioneiro com uma corda.

Arad (op. cit.) sugere, assim, que os nomes hammer e chain, por um lado, e os verbos to hammer e to chain, por outro, tenham as seguintes derivaçôes:
(6) nomes:
a) ${ }_{N}[\mathrm{~N}$ hammer $]$
b) ${ }_{\mathrm{N}}\left[\mathrm{N} \sqrt{ }_{\text {chain }}\right]$
(7) verbos:
a) ${ }_{\mathrm{v}}[\mathrm{V} \sqrt{ }$ hammer $]$
b) ${ }_{\mathrm{V}}\left[\mathrm{V}_{\mathrm{N}}\left[\mathrm{N} \sqrt{ }_{\text {chain }}\right]\right]$

De acordo com Arad (op. cit.), a presença de uma projeção nominal entre a raiz e a categoria verbal na derivação que a autora sugere para o verbo to chain, como em (7)b, impede qualquer tipo de acesso do verbo à raiz. A autora explica esse fato, formulando o princípio em (8), que restringe as interpretações possíveis para as raízes em diferentes domínios:

(8) Locality constraint on the interpretation of roots: "Roots are assigned an interpretation in the environment of the first category-assigning head with which they are merged. Once this interpretation is assigned, it is carried along throughout the derivation" (ARAD, 2003, p. 747). ${ }^{1}$

Esse princípio decorre naturalmente da proposta, em Marantz (2001), de que o primeiro núcleo funcional que determina a categoria sintática também determina a fronteira de um domínio cíclico, ou uma fase, conforme Chomsky (1999). Toda vez que um núcleo funcional " $x$ " se associa a uma raiz, ele fecha um ciclo e a categoria da qual ele é o núcleo é enviada para LF (forma lógica) e PF (forma fonética) para interpretação semântica e fonética. Nesse ponto da derivação, o significado da raiz é estabelecido e, mesmo que outro núcleo funcional tome a categoria xP como complemento, ele não vai poder estabelecer outro significado para a raiz. De acordo com Marantz (2001), o núcleo que toma $\mathrm{xP}$ como complemento só poderá ver os traços de " $\mathrm{x}$ " localmente. Isso quer dizer 
que os traços da raiz que se associou a "x" não são acessíveis para o segundo núcleo funcional que entra na derivação de uma palavra. Em outros termos, palavras que derivam de outras palavras não podem acessar os traços da raiz da qual derivam.

A observação dos dados de (9) a (11), paralelos do PB para as observaçóes de Arad (op. cit.) e Kiparsky (op. cit.) para o inglês, com a diferença de que envolvem nominalizações, e não apenas verbos, revela relações semelhantes entre verbos e nomes correspondentes.

(9) O João deu uma remada com a mão mesmo para se afastar da margem.

(10) *O João deu uma parafusada mais apertada nesses três pregos que sustentam a estrutura.

(11) *O João deu uma remada no ladrão com o porrete. ${ }^{2}$

Parece claro que as nominalizações remada e parafusada, em (1) e (3), derivam dos verbos remar e parafusar, enquanto que a nominalização remada, em (2), deriva do nome remo. No entanto, exemplos como os de (9) a (11) mostraram que, há certas dependências entre a nominalização e o nome cognato. Assim, entre as nominalizações derivadas de verbos, enquanto remada não requer, necessariamente, a presença do nome remo, parafusada não pode ocorrer na presença de prego, por exemplo. $\mathrm{O}$ mesmo se verifica com remada derivada do nome remo, que não pode ocorrer com porrete.

Esses fatos sugerem que remada, em (2) e (11), de fato, deriva do nome e, portanto, depende da sua prévia formação. Por outro lado, entre as nominalizaçōes derivadas de verbo, há um tipo, como remada, em que o verbo deriva diretamente da raiz, prescindindo da formação prévia do nome correspondente, como em (1) e (9), e outro, como parafusada, em que o verbo requer formação prévia do nome correspondente, nesse caso, parafuso, como se vê em (3) e (10). Assim, dados como esses constituem evidências para argumentar em favor da existência de três tipos de nominalizações em $\mathrm{PB}$, dependendo de sua correlação obrigatória ou não com um nome correspondente.

Os dados confirmaram a sugestão de Arad (op. cit.) de que algumas palavras derivam de raízes e algumas outras derivam de outras palavras (esse é o caso de todas as nominalizaçóes em -ada) e sugere a adequação da ideia de que o primeiro núcleo funcional que se associa à raiz determina uma fase, nos termos de Marantz (2001). 
Estava claro, portanto, que todo o processo de formação das CVLs era sintático, desde a formação de suas partes, até a formação da expressão complexa, ela mesma. E a MD, por suas características, surgia como modelo adequado para a análise desse fenômeno. Uma análise fundamentada em um modelo teórico como esse não poderia, por assim dizer, admitir uma visão lexicalista para a formação das CVLs, ou para qualquer outro fenômeno. Antes, trabalhos desenvolvidos a partir dessa perspectiva deveriam procurar buscar evidências que confirmassem a natureza sintática dos fenômenos observados nas línguas naturais. Esse modo de pensar me levou a formar o Grupo de Estudos em Morfologia Distribuída da USP - GREMD, sobre o qual passo a falar na próxima seção.

\section{A formação do GREMD - Grupo de Estudo em Morfologia Distribuída da USP}

O Grupo de Estudos em MD da USP (GREMD) teve seu início em agosto de 2004 a partir do interesse comum, meu e de meus alunos do curso de Linguística da USP, em ampliar nossos conhecimentos sobre esse modelo teórico. Como eu ainda não atuava no Programa de Pós-graduação e Semiótica e Linguística Geral da USP na época da formação do grupo, nossos encontros começaram com discussôes conduzidas por mim, das quais participavam somente alunos da graduação em Linguística. Esses mesmos alunos foram se graduando e ingressando na Pós-graduação. Assim, ao longo dos anos, o GREMD passou a contar com estudantes de graduação e de pós-graduação. Desde o começo, no entanto, seus encontros caracterizam-se pela apresentação de textos teóricos sobre o modelo da DM, ou de textos que detenham uma ligação direta com ele. Além disso, são discutidos textos de autoria dos integrantes do grupo. Em ambos os casos, institui-se um diálogo que possibilita introduzir o modelo aos alunos de graduação, uma vez que ele não é contemplado pelas disciplinas formais do bacharelado em Linguística, ao mesmo tempo que refina o conhecimento dos alunos de pós-graduação.

\section{Temas desenvolvidos por pesquisadores da USP}

Os trabalhos desenvolvidos pelos integrantes do GREMD se concentram na área de Teoria da Gramática e, dentro dela, se subdividem em dois polos: a sintaxe da sentença e a sintaxe da palavra. A ligação entre esses polos se faz por 
estudos que remetem às propriedades gerais do modelo da MD, bem como aos sistemas de interface que se estabelecem entre fonologia-morfologia-sintaxesemântica dentro desse modelo. Já que, para a MD, palavras e sentenças são formadas pelas mesmas operaçôes e no mesmo lugar da gramática, Morfossintaxe é a palavra chave deste grupo.

Entre as línguas estudadas pelo grupo estão o $\mathrm{PB}$, além do hebraico, o georgiano e o japonês, o que além de refletir uma abertura do grupo para o estudo das línguas em geral, reflete a pluralidade de temas nas pesquisas realizadas.

Desde sua formação, os integrantes do GREMD trabalham dentro de um projeto comum, que engloba as diferentes pesquisas do grupo de acordo com um determinado fio condutor. De 2005 até hoje, concluímos dois projetos e temos um terceiro em andamento.

O primeiro projeto, intitulado $A$ natureza do léxico e suas relações com a morfologia, a sintaxe e a semântica tinha o objetivo de contribuir para a discussão sobre o lugar da formação dos itens lexicais: dentro do léxico ou dentro da sintaxe? Esse projeto, desenvolvido de 2005 a 2010, contou com a minha participação, a de cinco alunos de mestrado e de alguns alunos de graduação. De modo geral, investigamos, principalmente, a morfologia, a sintaxe e a semântica das expressões linguísticas, além da sua fonologia, procurando descobrir as propriedades essenciais do léxico para, então, determinar se uma gramática que disponha de apenas um componente gerativo poderá dar conta da capacidade gerativa das línguas naturais. O projeto incluiu pesquisas sobre os seguintes temas:

i) o uso adverbial de adjetivos e objetos cognatos;

ii) a relação existente entre a marcação de Caso e definitude na língua hebraica;

iii) alternâncias de estrutura: alternância média no $\mathrm{PB}$ e alternâncias de estrutura argumental no georgiano;

iv) a hipótese de raízes abstratas e a ocorrência de coisa, coisar e derivados em Língua Portuguesa;

v) formação e interpretação de verbos denominais no PB;

vi) bitransitividade no $\mathrm{PB}$;

vii) formação de nominalizações e de nominais em PB;

viii) prefixação e composição em língua japonesa; 
ix) formação de blends no PB;

$\mathrm{x}$ tipos diversos de construçōes com o verbo acabar em PB; e

xi) verbos de transferência e movimento e a expressão do objeto indireto no PB.

No segundo projeto, de duração mais curta, tendo vigido de 2007 a 2009 e contado com a minha participação e a de um aluno de doutorado na fase inicial do desenvolvimento de seu projeto, investigamos aspectos morfossintáticos e semânticos das nominalizações no $\mathrm{PB}$ e no hebraico, visando a descrever e analisar seu comportamento nessas línguas com base no modelo de Princípios e Parâmetros e na MD. O tema principal, discutido no âmbito do projeto, foi "Nominalizações dentro de formações sintáticas mais complexas".

Finalmente, o terceiro projeto, em vigor desde 2011, conta com a minha participação e a dos demais membros do grupo. O projeto tem o objetivo de ampliar o escopo dos estudos em MD na pesquisa em Linguística feita no Brasil sobre o PB ou sobre outras línguas naturais. Com esses trabalhos, pretendemos identificar, nas línguas em foco, propriedades mais gerais das línguas naturais. Estamos fazendo isso por meio de discussões acerca dos seguintes tópicos, sempre fundamentadas pelo modelo da MD e focando línguas como o $\mathrm{PB}$, o espanhol peninsular (EP), o inglês, o japonês, o georgiano, russo e o hebraico:

i) processos de formação de palavras, concatenativos ou não, nas línguas naturais;

- prefixação de negação e de repetição no PB;

- prefixação de formalidade e composição no japonês;

- $\quad$ sufixação para a formação de verbos denominais em PB;

- sufixação para formação de nomes em PB;

- formação de nominalizações em PB e em hebraico

- formação de termos aumentativos e diminutivos no PB e em outras línguas românicas;

- formaçóes do tipo de mesclagem e truncamento em PB e EP

ii) estrutura argumental de predicados verbais, nominais e adjetivais;

iii) geometria de traços para os sistemas pronominais e flexionais do PB;

iv) sincretismo passivo reflexivo em línguas como o russo, o georgiano e o PB;

v) formas causativas sintéticas no PB; 
vi) construções resultativas;

vii) predicados complexos;

viii) parâmetro da composicionalidade e a morfologia distribuída;

ix) auxiliares, aspectuais e modais; e

$\mathrm{x}$ particípios inovadores no PB.

Esse conjunto de pequenos projetos temáticos e de projetos de pesquisa individuais incluídos neles tem causado a convergência de um grupo de pesquisadores, grande parte deles, em formação, em torno de um modelo de análise linguística que tem se mostrado coerente e adequado para o desenvolvimento das pesquisas mencionadas.

Para pesquisas a serem realizadas em um futuro próximo, o grupo pretende se dedicar mais detalhadamente às relações que se estabelecem entre a morfologia e a semântica. Não menos importante, no entanto, é o fato de que tem ficado claro para os membros do GREMD que não poderá ficar de fora de nossos propósitos a pesquisa com línguas indígenas e línguas de sinais. Finalmente, mais recentemente, passou a fazer parte de nossos objetivos a pesquisa que relaciona linguística formal a textos literários. Em particular, nos moldes de Faab (2002), nosso interesse recai sobre o papel da cognição nos textos literários, e a pergunta principal, como colocada pelo próprio autor, é se, de fato, regras literárias, tais como métrica, paralelismo, rima, ou aliteração, por exemplo, representam algum processo cognitivo especializado e se, de alguma forma, tal processo tem alguma relação com processos cognitivos linguísticos de modo geral.

A opção pelo modelo da MD se fez por suas características e pelas possibilidades de análise que ele oferece e que superam, com vantagens, modelos em que um componente lexical faz parte da arquitetura da gramática. Entre outras coisas, um modelo lexicalista, que assume que as palavras entram prontas na derivação sintática, encontra dificuldades para dar conta da ambiguidade observada para nominalizaçôes como remada, como apontado acima. Modelos como esse também não oferecem tratamentos satisfatórios para casos de alternância, tais como a alternância causativo-incoativa, sendo comum encontrar, na literatura, tanto explicações que assumem que a forma incoativa deriva da forma causativa quanto a asserção contrária. A explicação que a DM oferece para casos de alternância como esse pode ser bastante simples, na medida que sugere, em linhas bem gerais, que as formas alternantes derivam da presença da mesma 
raiz em estrutura sintáticas distintas, oferecendo, assim, um tratamento sintático, e não lexical ou mesmo morfológico, para um fenômeno bastante comum, mas bem controverso, das línguas naturais.

\subsection{Morfologia Distribuída na Universidade Federal de Santa Catarina e na Universidade federal do Paraná: Depoimento de Maria Cristina Figueiredo Silva, Professora Associada do Departamento Linguística, Letras Clássicas e Vernáculas da UFPR}

A minha paixão por morfologia nasceu já há algum tempo, quando fui instada a dar a disciplina de morfologia na graduação e no programa de pósgraduação da UFSC, lá nos idos anos 90 . Na graduação, o programa era fundamentalmente a morfologia estruturalista, com a leitura obrigatória de Mattoso Camara Jr. Ainda que a genialidade desse autor cedo tenha ficado evidente para mim, a verdade é que num quadro teórico puramente descritivo não é possível fazer grande coisa...

No curso de pós-graduação, havia uma disciplina obrigatória de Morfologia, que em seu programa original era essencialmente uma disciplina de lexicologia. Quando fui ministrar essa disciplina, inseri o conteúdo de morfologia gerativa, que eu pouco conhecia, na verdade. O manual adotado foi o de Andrew Spencer, da Blackwell, excelente para mostrar todo o histórico da disciplina, suas questóes candentes, seus problemas sem solução.

E porque a paixão pela morfologia foi me tomando, eu fiz o meu primeiro projeto de pesquisa para o CNPq na interface com a sintaxe, para o biênio 20012002. O projeto se intitulava $O$ lugar da morfologia na sintaxe, e procurava responder uma questão de morfologia flexional (a distribuição dos tempos do subjuntivo, uma questão aventada, na verdade, por Mattoso Camara Jr. em seu Estrutura da língua portuguesa) e uma questão de morfologia derivacional (relativa à formação 'dar uma X-ada', na época sendo estudada também por Ana Paula Scher). Esse era um projeto que comparava LGB com o Programa Minimalista na solução desses problemas, mas o que ficou claro para mim na época é que finalmente trocávamos seis por meia dúzia, porque havia pouco a dizer nos dois quadros sobre a morfologia derivacional e porque avançávamos pouco com respeito à morfologia flexional. 
Este projeto foi interrompido pelo pós-doutorado em Portugal, de setembro de 2002 até julho de 2003, com o Professor João Costa, da UNL. Em princípio, era um pós-doutorado em sintaxe, mas foi ali que primeiro tomei contato com a MD. A questão que tínhamos para resolver era o problema da concordância no $\mathrm{PB}$ e no português europeu (doravante $\mathrm{PE}$ ), um problema para o qual os sintaticistas têm procurado soluções sintáticas, em vão. E João Costa, inspirado por um artigo de Embick e Noyer que tinha sido publicado na Linguistic Inquiry em 2001, sugeriu utilizarmos a noção de morfema singleton para explicar a diferença entre a presença massiva de marcas de concordância de número e pessoa no sistema verbal e nominal no PE contra a sua ausência praticamente total em alguns dialetos do $\mathrm{PB}$. Apresentamos esse trabalho em alguns congressos na Europa e ele está publicado em sua versão final em Costa e Figueiredo Silva (2006).

A ideia desenvolvida nesse texto é que o efeito de concordância visível pode tanto ser resultado de movimento de núcleo na sintaxe quanto de processos morfológicos. Além disso, morfemas podem ser realizados ou em uma única categoria (morfema singleton), ou em várias categorias (como um morfema dissociado). Assim, a presença de marcas de número em todos os elementos num sintagma nominal que vemos em PE é derivada da presença de morfemas dissociados que, de acordo com Embick e Noyer (2001), é um fenômeno morfológico, não sintático. Por outro lado, certas configurações sintáticas específicas como Spec-head agreement podem ter como efeito a realização visível de morfemas de plural e de pessoa.

Eu não estou muito certa de que entendi imediatamente as consequências dessa nova maneira de ver o problema da concordância - tampouco tenho essa certeza hoje, é preciso dizer. Tirar esse fenômeno da alçada direta da sintaxe envolve mais do que um modo técnico elegante de resolver o problema, porque a maneira tradicional de tratar questôes como a do sujeito nulo nas línguas naturais envolve crucialmente o cruzamento de fatores estruturais com a presença de marcas morfológicas - basta ver o clássico texto de Rizzi (1986) para ver inclusive o alcance dessa abordagem para além dos muros do sujeito nulo. No entanto, também é verdade que ligar diretamente a presença de morfemas de plural ou pessoa a configuraçôes sintáticas estritas tem nos criado muitos becos sem saída, teóricos e empíricos, em especial no domínio nominal. Eé por isso que a saída da MD, que circunda o problema das marcas ao domínio morfológico, me pareceu e ainda me parece tão atraente, razão pela qual também é dessa forma 
que explicamos, Miriam Lemle e eu, o problema da suposta 'falta de concordância' no PB (cf. LEMLE; FIGUEIREDO SILVA, 2011).

Outros aspectos da MD também me pareciam atraentes, mesmo que eu não soubesse exatamente o que fazer com eles. Por exemplo, o fato mesmo de não existir mais um léxico único e poderoso em que são construídas as palavras resolve inúmeros problemas morfológicos, a começar pela definição mesma do que é 'palavra', por mais intuitiva que pareça essa entidade. Além disso, todos os problemas com os quais a semântica lexical era instada a lidar nas abordagens tradicionais são divididos entre as diferentes listas da MD, separando crucialmente o que é informação propriamente lexical do que é conhecimento de mundo.

Mas não foi imediatamente que eu adotei a MD nos meus trabalhos. De volta à UFSC em 2003, ainda escrevi alguns trabalhos em morfologia gerativa tradicional, com muita dificuldade de abandonar certas ideias, como a de seleção de um prefixo pela sua base (veja, por exemplo, FIGUEIREDO SILVA; MIOTO, 2009), e sem saber como formulá-las na MD. Em certos casos, não cabia escolher a abordagem MD porque o trabalho tinha caráter introdutório, seja do ponto de vista teórico (por exemplo, o material instrucional que eu escrevi para o curso de graduação a distância Letras-Libras, em 2006), seja do ponto de vista empírico (cf. FIGUEIREDO SILVA; SELL, 2011, que trabalham fundamentalmente com os compostos de Libras).

Foi no trabalho com os alunos, especialmente os de doutorado, que comecei a explorar certos caminhos que a MD abria, mesmo porque, em alguns casos, a dissertação de mestrado já havia mostrado os limites da morfologia gerativa tradicional (cf., por exemplo, OLIVEIRA, 2004). Defendida em 2006, a tese de doutorado de Ana Luzia Dias Pereira, sobre a distribuição dos pronomes clíticos no $\mathrm{PB}$, foi talvez o primeiro lugar em que, dada a insuficiência do tratamento tradicional em sintaxe e em morfologia, a MD foi adotada incondicionalmente, ainda que talvez timidamente - hoje eu sei que o trabalho poderia ter abarcado todo o grupo dos pronomes ditos pessoais do $\mathrm{PB}$. As duas outras teses que eu orientei em morfologia na UFSC foram no quadro MD, uma tratando da distribuição de - ga e - wa no japonês (cf. FUCHS, 2009) e outra retomando a questão da afixação no PB (cf. OLIVEIRA, 2009). Quando ingressei no programa de pós-graduação em Letras da UFPR, em 2009, inscrevi um projeto de pesquisa em morfologia, sobre a diferença entre prefixação e composição, um assunto que me interessa faz tempo e para o qual a morfologia tradicional não tem solução imediata. E é nesse projeto que venho inserindo o meu trabalho em MD, esperando alunos valentes para esse estudo. 
Evidentemente, está implícito em tudo o que foi dito até aqui que a MD aporta um conhecimento que não seria facilmente formulável em outro arcabouço teórico. Vou dar um exemplo de um artigo produzido por uma orientanda, Solange Mendes de Oliveira. O artigo trata da distribuição dos sufixos nominalizadores -ção e -mento, um problema para o qual a morfologia gerativa tradicional não tem uma generalização a propor - fala-se em tendências (cf. BASÍlLIO, 1996), mas não é claro por que as coisas seriam desse modo. Inspirada no trabalho de Lemle (2002) sobre afixação em verbos, Oliveira (2007) mostra que a escolha por -ção ou -mento depende de certas propriedades aspectuais das raízes com as quais cada um dos sufixos se combina. Ora, esse tipo de explicação tira a morfologia derivacional daquele território incógnito, em que as coisas acontecem (ou não acontecem) por alguma razão desconhecida, e traz toda a explicação para nós aspectuais projetados na estrutura, perfeitamente predizíveis dado o significado da raiz. Esse é um resultado não trivial que nos faz avançar no conhecimento de como a língua é.

Além disso, é inegável que a MD, pela própria arquitetura da gramática que abraça, consegue colocar para conversar pedaços de conhecimento antes díspares, recolhidos em rincôes distintos e incomunicáveis da gramática. Um exemplo é o caso de formaçóes compostas (como quebra-nozes) e formações idiomáticas (como quebrar o gelo). Que elas se aparentam pela forma, parece indiscutível, mas nas teorias tradicionais (mesmo gerativas) de morfologia ou sintaxe não era possível tentar estabelecer qualquer parentesco real.

Atualmente estou explorando as possibilidades de encontro dessas construções. No VII Congresso Internacional da ABRALIN, no começo de 2011 em Curitiba, formamos Ana Scher, Miriam Lemle e eu uma mesa-redonda intitulada 'Distribuindo morfologia: desdobramentos recentes da morfologia distribuída', em que apresentei os primórdios dessa pesquisa, um trabalho intitulado 'Sobre a distinção entre composição e expressões idiomáticas' embora o título fale de distinção, eu procurava mesmo é a semelhança entre elas, em particular entre aquelas que têm a forma verbo + complemento. A proposta foi estender e adaptar uma análise da composição formulada em Harley (2008) para as expressóes idiomáticas. Essas ideias ainda devem ser trabalhadas, mas eu estou confiante de que é esse quadro teórico que vai me permitir formular as questóes pertinentes e encontrar as respostas adequadas para elas. 


\section{CONCLUSÕES}

O leitor teve acesso aqui à pesquisa de quatro estudiosos da MD no Brasil e, assim, conhece agora um pouco do pensamento característico dessa abordagem e os dados que ela nos ajuda a compreender e explicar de maneira interessantemente inovadora em relação à proposta lexicalista da teoria tradicional de morfologia, gerativa ou não. Desse modo, esperamos ter mostrado ao leitor as vantagens do modelo, que justificam plenamente nossa opção.

O que talvez não tenha ficado tão claro - e agora seria a hora de aclarar é esse mapa que um dos contribuidores do texto, Miriam Lemle, chamou de "órgáo da mente", comparado a uma orquestra. A metáfora da orquestração é interessante porque fala, ao mesmo tempo, da modularidade, da especificidade de cada módulo e da afinação de timbres que eles devem ter entre si para poderem conversar estamos falando aqui da interface interna ao modelo entre a sintaxe, a morfologia e a fonologia, por um lado, a sintaxe e os sistemas de interpretação semântica, incluindo a interpretação enciclopédica, por outro. Para que a ideia seja mais que uma metáfora e adquira credibilidade, é preciso mostrar quais são os módulos desse órgão mental, qual é o input de cada um, qual éa computação que cada um realiza, qual tipo de informação cada módulo entrega para o outro, de tal modo que, ao término de sua tarefa complexa, o órgão da linguagem entregue comandos sobre produção de sons da fala (ou sinais manuais) estruturados em constituintes, de um lado e, de outro, esquemas sintáticos também estruturados em constituintes, legíveis semanticamente como porçôes de evento-e-participantes, revestíveis com detalhes de percepção de maneiras, estes últimos provenientes de módulos ligados em última análise às percepçôes-do-mundo. A MD tem um desenho interno capaz de fornecer respostas claras para essas demandas, de tal modo que elas possam ser testadas contra os fatos das línguas naturais.

É um pouco preocupante a postura pseudo-politicamente correta, bastante em voga atualmente, de que teorias alternativas devem conviver fraternalmente, do mesmo modo que convivem diferentes raças, línguas, culturas, religiōes e preferências artísticas ou sexuais existentes na sociedade. Embora tal postura no terreno social seja, mais que aceitável, desejável, no terreno da ciência, com essa mentalidade igualitarista se desvanece a preocupação pela busca da melhor teoria, aquela que explica melhor os dados e abre possibilidade de vermos novos fenômenos até então invisíveis. É batendo nessa tecla filosófico-epistemológica que gostaríamos de terminar este nosso artigo. 


\section{Notas}

* Bolsista PQ II, Processo no. 309257/2009-3.

${ }^{1}$ Restrição de localidade na interpretação de raízes: Atribui-se uma interpretação para raízes no ambiente do primeiro núcleo atribuidor de categoria com o qual elas são concatenadas. Uma vez atribuída, essa interpretação é levada ao longo de toda a derivação. ${ }^{2}$ Miriam Lemle me apontou que o exemplo em (9) "fica inaceitável se substituirmos com a mão por com o parafuso, com o punhal, com o revolver, com o saca-rolha, com a chave de parafuso, com a pena,", entre outros, "pois essas coisas não se prestam à função pragmática 'empurrar água'. Para a pesquisadora, "essas substituições ficariam tão inadequadas quanto o são os exemplos (10) e . A semelhança entre o funcionamento de mão humana e remo dentro d'água no mundo como ele é conhecido por nós basta para explicar por que razão 'mão' fica OK em (9), que fala em margem que, por sua vez, se liga a rio, que é um curso d'água. Mas nomes de trecos que não se prestam para exercer a função de 'empurrar água' não se adequam. A raiz vrem- ativa um componente 'maneira hidro-empurrante' que basta para explicar os contrastes de aceitabilidade nesse caso". A autora acrescenta que "a inaceitabilidade de tem a ver com a propriedade 'maneira hidroempurrante' porque a explicitação de que a remada foi num ladrão e com porrete contradiz a expectativa de hidro-empurrância em remada, dando um paradoxo.

Observação semelhante foi feita por Maria Cristina Figueiredo Silva sobre o exemplo em (10). Para a autora, uma sentença como "O João deu uma parafusada no gancho do varal" pode ser bem formada. Meu julgamento e o mesmo. De acordo com ela, "prego não pode ser parafusado, por conta do movimento característico de parafusar, mas gancho de varal pode ser 'parafusado' nesse sentido". Nos termos de Miriam Lemle, o exemplo em (10) "também tem sua inaceitabilidade explicável por vias da semântica 'maneira' da raiz, pela diferença de funcionamento entre prego e parafuso, pois o funcionamento de parafuso se baseia na maneira 'giro da haste dotada de uma espiral torneada através de outra espiral complementar esculpida na superfície receptora da haste', ao passo que a 'maneira' atuante do prego consiste somente na 'penetração sob pressão abrupta da haste na superfície receptora'.” Nos dois casos, portanto, há um componente "maneira" das raízes que pode ser determinante para a boa formação das sentenças.

\section{Referências}

ALEXIADOU, A. Functional Structure in Nominals: Nominalization and Ergativity. Amsterdam: John Benjamins, 2001.

ARAD, M. Locality Constraints on the interpretation of roots: the case of Hebrew denominal verbs. NLLT, 21, p. 737-778, 2003. 
BASÍLIO, M. Formação e uso da nominalização deverbal sufixal no português falado. In: CASTILHO, A.; M. BASÍLIO (Org.). Gramática do português falado. Vol. IV. Campinas: UNICAMP/FAPESP, 1996. p. 23-30..

BORER, H. Roots and Categories. COLLOQUIUM ON GENERATIVE GRAMMAR, 19th Abril de 2009, Proceedings... University of the Basque Country.

BORER, H. The grammar machine. In: ARTEMIS, A.; AGNOSTOPOULOU; M. EVERAERT (Ed.). The Unaccusativity Puzzle: Explorations of the Syntax-Lexicon Interface. Oxford: Oxford University Press, 2004. p. 288-331.

BORER, H. Structuring Sense. Oxford: Oxford University Press, 2005.

CAMPBELL, R. G. The Grammatical Structure of Verbal Predicates. 1989. Tese (Doutorado) - UCLA, Los Angeles, 1989.

CASTRO, C. S.; LEMLE, M. Composicionalidade semântica em LSB - fronteiras e encaixes. In: SALLES, H. M. L.; R. R NAVES (Org.). Estudos de lingua de sinais brasileira e aquisiçāo do português $\left(L_{2}\right)$ por surdos. Goiânia: Cânone Editorial, 2010. p. 109-150.

CASTRO, C. S. Composicionalidade semântica em Libras: fronteiras e encaixes. 2007. Tese (Doutorado) - UFRJ, Rio de Janeiro, 2007.

CHOMSKY, N. Derivation by phase. MITOPL 18, 1999. [Reeditado em KENSTOWICZ, M. (Ed.). Ken Hale: a Life in Language. Cambridge, Mass.: The MIT Press, 2001. p. 1-52].

CHOMSKY, N. The Minimalist Program. Cambridge, Mass.: The MIT Press, 1995.

CHOMSKY, N. Lectures on Government and Biding. Dodrecht, The Netherlands: Foris, 1981.

CHOMSKY, N. Remarks on Nominalization. In: JACOBS, R.; ROSENBAUM, P. (Ed.). Readings in English Transformational Grammar. Waltham, MA: Ginn and Co., 1970. [Reeditado em CHOMSKY, N. Studies on Semantics in Generative Grammar. The Hague: Mouton, 1972. p. 11-61]

CHOMSKY, N. Aspects of the Theory of Syntax. Cambridge, Mass.: The MIT Press, 1965.

CHOMSKY, N. Syntactic Structures. The Hague: Mouton, 1957.

COSTA, J.; FIGUEIREDO SILVA, M. C. Nominal and Verbal Agreement in Portuguese: an Argument for Distributed Morphology. In: Agreement. Amsterdam: John Benjamins, 2006. p. 25-46. (Org.). Studies on

DUBINSKY, S. Syntactic underspecification and light-verb phenomena in Japanese. Linguistics 35, p. 627-672, 1997. 
EMBICK, D. On the Structure of Resultative Participles in English. Linguistic Inquiry, 35. p. 355-392, 2004.

EMBICK, D.; NOYER, R. Movement Operations after Syntax. Linguistic Inquiry, 32, p. 555-595, 2001.

FAAB, N. Linguistics and Literature. In: ARONOFF, M.; J. REES-MILLER (Ed.). The Handbook of Linguistics. Blackwell Publishing, 2002.

FIGUEIREDO SILVA, M. C. Morfologia. Material instrucional disponibilizado em rede para o curso de licenciatura à distância Letras-Libras. Florianópolis: Universidade Federal de Santa Catarina, 2006.

FIGUEIREDO SILVA, M. C.; MIOTO, C. Considerações sobre a prefixação. Revista Virtual de Estudos da Linguagem, v. 7, 2009. Disponível em: <http:// www.revel.inf.br/files/artigos/revel_12_consideracoes_sobre_a_prefixacao.pdf $>$.

FIGUEIREDO SILVA, M. C.; SELL, F. F. Algumas notas sobre compostos em português brasileiro e em Libras. In: PIRES DE OLIVEIRA, R.; MIOTO, C. (Org.). Percursos em Teoria da Gramática. Florianópolis: Editora da UFSC, 2011. p. 17-41.

FIGUEIREDO SILVA, M. C. Sobre a distinção entre composição e expressões idiomáticas. Apresentação na Mesa redonda "Distribuindo Morfologia: desdobramentos recentes da Morfologia Distribuída". CONGRESSO INTERNACIONAL DA ABRALIN, VII, fevereiro/2011, Anais... Curitiba, Brasil.

FILLMORE, C. The Case for Case. In: BACH, E.; R.T. HARMS (Ed.). Universals in Linguistic Theory. New York: Holt, Rinehart and Winston, 1968.

FRANÇA, A. I. O léxico mental em ação: muitas tarefas em poucos milissegundos. LinguíStica, UFRJ, 1, p. 45-80, 2005.

FRANÇA, A. I. Concatenações linguísticas: estudo de diferentes módulos cognitivos na aquisição e no córtex. 2002. Tese (Doutorado) - UFRJ, Rio de Janeiro, 2002.

FUCHS, C. Y. Os marcadores -ga e -wa em japonês: um estudo dos traços morfossintáticos e semânticos para a inserção vocabular. 2009. Tese (Doutorado) - Universidade Federal de Santa Catarina, Florianópolis, 2009.

GRIMSHAW, J. Argument Structure. Cambridge, Mass.: The MIT Press, 1990.

GRIMSHAW, J.; MESTER, A. Light verbs and $\theta$-marking. Linguistic Inquiry, 19. p.205-232, 1988.

GRODZINSKY, Y. The battle for Broca's region. Trends in Cognitive Science, 12, p. 474480, 2008. 
HALE, K.; KEYSER, S. J. On Argument Structure and the Lexical Expression of Syntactic Relations. In: HALE, K.; S. J. KEYSER (Ed.). The View From Building 20, Cambridge, Mass.: The MIT Press, 1993, p. 53-109.

HALE, K.; KEYSER, S. J. Prolegomenon to a Theory of Argument Structure. Cambridge, Mass.: The MIT Press, 2002.

HALLE, M.; MARANTZ, A. Some Key features of Distributed Morphology. MIT Working Papers in Linguistics 21, p. 275-288, 1994.

HALLE, M.; MARANTZ, A. Distributed morphology and the pieces of inflection. In: HALE, K.; S. J. KEYSER (Ed.). The View From Building 20, Cambridge, Mass.: The MIT Press, 1993, p. 111-176.

HARLEY, $\mathrm{H}$. The bipartite structure of verbs cross-linguistically. CONGRESSO INTERNACIONAL DA ABRALIN, Anais... UFMG, 2007.

HARLEY, H.; NOYER, R. State-of-the-article: Distributed Morphology. Glot International 4.4, p. 3-9, 1999.

IPPOLITO, M. On the past participle morphology in Italian. MIT Working Papers in Linguistics 33. p. 111-137, 1999.

JACKENDOFF, R. Semantic Structures. Cambridge, Mass.: The MIT Press, 1990.

KIPARSKY, P. Word formation and the lexicon. In: INGEMAN, F. (Ed.). MID-AMERICA LINGUISTICS CONFERENCE, Proceedings... Kansas: University of Kansas, 1982.

KRATZER, A. Severing the External Argument from its Verb. In: ROORYCK, J.; L. ZARING (Ed.). Phrase Structure and the Lexicon. Dodrecht: Kluwer Academic Publishers, 1996. p. 109-137.

KRATZER, A. "Building Statives". 2000. Disponível em: <http://semanticsarchive. net/Archive/GI5MmI0M/kratzer.building.statives.pdf>. Acesso em: 18 abr. 2003. LAGE, A. C. Aspectos neurofisiológicos de concatenação e idiomaticidade em português do Brasil: um estudo de potenciais bioelétricos relacionados a eventos linguísticos (ERPs). 2005a. Tese (Doutorado) - UFRJ, Rio de Janeiro, 2005a.

LAGE, A. C. Concatenações do objeto em português e no alemão. Conclusões de experimentos psicolinguísticos on-line. LinguíStica, UFRJ, 1, p. 81-108, 2005 b.

LEMLE, M.; CASTRO, C. S. Polissemia em verbos segundo uma abordagem Exoesqueletal. In: NAVES, R. R.; H. M. L. SALLES (Org.). Estudos Formais da Gramática das Linguas Naturais. Goiânia: Cânone Editorial, 2012. p. 217-226.

LEMLE, M.; FIGUEIREDO SILVA, M. C. Variação na expressão da concordância: muitas gramáticas e muitos gramáticos. Ensino de Morfologia. ECLAE, V, setembro/ 2011, Anais... Natal, Brasil. 
LEMLE, M. Arbitrariedade saussureana, saltos e sobressaltos. XXIII Reunião anual da ANPOLL, UFG, 2008. Ms. 36p.

LEMLE, M. Mudanças sintáticas e sufixos latinos. LinguíStica, UFRJ, 1, p. 5-44, 2005.

LEMLE, M. Sufixos em verbos: onde estão e o que fazem. Revista Letras, UFPR, 58, p. 279-324, 2002.

LEMLE, M. O novo estruturalismo em lingüística: Noam Chomsky. Tempo Brasileiro, 15/16: Estruturalismo. Rio de Janeiro, p. 60-65, 1967.

LEVIN, B.; RAPPAPORT HOVAV, M. Unaccusativity: At the Syntax-Lexical Semantics Interface. Cambridge, Mass.: The MIT Press, 1995.

LEVINSON, L. The Roots of Verbs. 2007. Tese (Doutorado) - New York University, Nova Iorque, 2007.

LIN, J. Event Structure and the Encoding of Arguments: The Syntax of the Mandarin and English Verb Phrase. 2004. Tese (Doutorado) - MIT, 2004.

MARANTZ, A. Argument Structure and Morphology: Noun Phrases that Name Events, Manuscrito, New York University, 2006.

MARANTZ, A. Words. Apresentação feita no WCCFL 2001, como Keynote Speaker. Califórnia: USC, 2001.

MARANTZ, A. No escape from syntax: don't try morphological analysis in the privacy of your own lexicon. In: DIMITRIADIS, A. et al. (Ed.). ANNUAL PENN LINGUISTICS COLLOQUIUM, 21th, Proceedings... University of Pennsylvania Working Papers in Linguistics, v. 4.2. p. 201-225. 1997.

MEDEIROS, A. B. Considerações sobre o prefix re-. Revista Alfa (no prelo).

MEDEIROS, A. B. Para uma abordagem sintático-semântica do prefixo des-. Revista da ABRALIN, v. 9, n.2. p. 95-121, 2010.

MEDEIROS, A. B. Traços morfossintáticos e subespecificação morfológica na gramática do Português: um estudo das formas participiais. 2008. Tese (Doutorado) Universidade Federal do Rio de Janeiro, Rio de Janeiro, 2008.

MEDEIROS, A. B. Sintaxe e semântica do particípio passado. 2004. Dissertação (Mestrado) - Universidade Federal do Rio de Janeiro, Rio de Janeiro, 2004.

MEDEIROS, A. B. Os sufixos nominalizadores -ção e -mento. Estudos Lingüisticos XXXVI (1), p. 89-96, 2007.

MEDEIROS, A. B. Aspectos da derivação prefixal e sufixal no português do Brasil. 2009. Tese (Doutorado) - Universidade Federal de Santa Catarina, Florianópolis, 2009. 
OLIVEIRA, S. M. Derivação Prefixal: um estudo sobre alguns prefixos do Português brasileiro. 2004. Dissertação (Mestrado) - Universidade Federal de Santa Catarina, Florianópolis, 2004.

PARSONS, T. Events in the Semantics of English: A Study in Subatomic Semantics. Cambridge, Mass.: The MIT Press., 1990.

PEREIRA, A.L. Os pronomes clíticos do PB contemporâneo na perspectiva teórica da Morfologia Distribuida. 2006. Tese (Doutorado) - Universidade Federal de Santa Catarina, Florianópolis, 2006.

PESETSKY, D. Zero Syntax - Experiencers and Cascades. Cambridge, Mass.: The MIT Press, 1995.

PYLKKÄNEN, L. Causation and external arguments. MIT Working Papers in Linguistics, v. 35, p.161-183, 1999.

PYLKKÄNEN, L. Introducing Arguments. 2002. Tese (Doutorado) - MIT, 2002.

RAMCHAND, G. Verb Meaning and the Lexicon: A First Phase Syntax. Cambridge: Cambridge University Press, 2008.

RIZZI, L. Null objects in Italian and the theory of pro. Linguistic Inquiry, 17, p. 501-557, 1986.

SCHER, A. P.; MEDEIROS, A. B.; MINUSSI, R. D. Estrutura Argumental em Morfologia Distribuída. In: NAVES, R. R.; SALLES, H. M. L. (Org.). Estudos Formais da Gramática das Linguas Naturais. Goiânia: Cânone Editorial, 2012. p. 175-198.

SCHER, A. P. Nominalizações em -ada em Construções com o Verbo Leve dar em Português Brasileiro. Letras de Hoje, v. 41, no 1. p.XX, 2006.

SCHER, A. P. As Construçōes com o Verbo Leve dar e as Nominalizaçôes em -ada no Português do Brasil. 2004. Tese (Doutorado) - UNICAMP, Campinas.

SPENCER, A. Morphological Theory. Londres: Blackwell, 1993.

STOWELL, T. Elements of Phrase Structure. 1981. Tese (Doutorado) - MIT, 1981.

TENNY, C. The Aspectual Interface Hypothesis. In: SAG, I. A.; SZABOLCSI, A. (Ed.). Lexical Matters. Stanford: Standford University, 1992. p. 1-27. 